University of Nebraska - Lincoln

DigitalCommons@University of Nebraska - Lincoln

Faculty Publications and Creative Activity, School of Theatre and Film

Theatre and Film, Johnny Carson School of

$11-1987$

\title{
Shakespeare in the Weimar Republic
}

William Grange

University of Nebraska-Lincoln, wgrange@unl.edu

Follow this and additional works at: https://digitalcommons.unl.edu/theatrefacpub

Part of the Theatre and Performance Studies Commons

Grange, William, "Shakespeare in the Weimar Republic" (1987). Faculty Publications and Creative Activity, School of Theatre and Film. 3.

https://digitalcommons.unl.edu/theatrefacpub/3

This Article is brought to you for free and open access by the Theatre and Film, Johnny Carson School of at DigitalCommons@University of Nebraska - Lincoln. It has been accepted for inclusion in Faculty Publications and Creative Activity, School of Theatre and Film by an authorized administrator of DigitalCommons@University of Nebraska - Lincoln. 
William Grange

\section{SHAKESPEARE IN THE WEIMAR REPUBLIC}

$\mathbf{T}$ he Weimar Republic occupies a period in German history that has long fascinated students of theatre and drama. It was a period of profound change in German social, political, and cultural experience, and rarely has the confluence of those experiences figured so influentially upon the performance of William Shakespeare's plays. In decades previous to Weimar, German Shakespeare productions manifested the awed reverence in which the playwright was held, since most German actors, directors, and designers regarded Shakespeare in the same light as they did Goethe and Schiller. In 1864, for example, Germany celebrated the three-hundredth anniversary of the playwright's birth with the founding of the Deutsche Shakespeare Gesellschaft and the proclamation that Shakespeare was not "a foreign poet, but one which England must share with us, due to his inborn Germanic nature."I In the Weimar Republic, however, the view of Shakespeare as playwright changed; it did so perhaps because everything else was changing in that volatile period, and also because Weimar culture encouraged innovation and experimentation. The republic itself, after all, was an experiment. If in retrospect the Weimar Republic's experimentation with democracy seems a failure, its success and achievement in painting, architecture, music, literature, and theatre cannot be denied. One overlooked area of particular achievement is the work of Weimar theatre artists who succeeded in their attempts to dismantle Shakespeare's status as a cultural icon.

That Shakespeare had entered the German pantheon of leading cultural lights was due to his enshrinement by the cultural Establishment; but it was due in equal measure to the enormous popularity among audiences of the Schlegel-Tieck translations which made the plays more accessible. Their 
accessibility is what made Shakespeare the leading playwright of the Weimar Republic, even though the vast majority of productions of Shakespeare plays were of the "traditional" variety, of which Max Reinhardt's $A$ Midsummer Night's Dream is the best example. ${ }^{2}$ There are seven productions of Shakespeare's plays during the Weimar Republic that stand out above the rest; they were productions that altered the German view of a playwright who already enjoyed a unique status, and they were unique productions because they opened new avenues of expression for "the Shakespearean spirit" (as Gerhart Hauptmann explained it). ${ }^{3}$ These productions made Shakespeare's plays aktuell by infusing them with a pertinence to contemporary life in the new republic, and they established new standards for Shakespearean performance with their sociological and political emphasis. In so doing they created controversies never before witnessed by German Shakespeare audiences. After these productions, Shakespeare for the Germans would never be the same again.

The artists responsible for the productions seemed intent upon wrenching Shakespeare from the clutches of the "decadent" Establishment, for they felt that certain of Shakespeare's plays identified closely with the "new age" in republican Germany. They were artists like the actor Fritz Kortner, whose portrayals of Gloucester, Macbeth, and Shylock were revolutionary in their use of movement and voice; the designers Emil Pirchan, Caspar Neher, and Cesar Klein, who dispensed with then-customary conventions of Shakespearean staging and created symbolic structures on an essentially limitless and neutral stage space; finally and most importantly, these productions bore the imprint of directors like Ludwig Berger, Erich Engel, Jürgen Fehling, and Leopold Jessner. Their work combined a deeply felt regard for the world of Shakespeare's dramas with an acute awareness of the "real" world outside the theatre. What follows here is an account of important productions which, with their consciousness of the strife which ultimately tore apart the Weimar Republic, served as "grave witnesses of true experience."

Ludwig Berger (1892-1967) was the first of the new directors whose work altered perceptions of Shakespeare. His production of Cymbeline, which opened October 10,1919, represented a total departure from productions of the Wilhelminian period. "My career began with a rage against the house curtain," Berger exclaimed, and he proceeded to stage Cymbeline accordingly. ${ }^{4}$ This excluded not only the house curtain, but elaborate scenery and "atmosphere" as well. "Shakespeare's actor," he said, "stood in an empty space. He had no other means at his disposal than his own body and his own voice. His art grew out of movement and words." Berger thus ordered the orchestra pit of the Deutsches Theater in Berlin covered, which permitted more playing room downstage; upstage center he placed a wall and gateway 
arch, bordered by side curtain legs, which also facilitated entrances and exits. Above the archway was a bridge unit where the scenes "above" took place. Conspicuously missing were, as Berger termed them, "seating opportunities for the actor." The set replicated, in effect, the Elizabethan platform stage. But why Cymbeline in the first place? A rarely performed work unknown to most audiences, the play's principal action concerns the misfortunes of a faithful wife who, owing to a simple misunderstanding, is scorned, maligned, threatened with murder, and otherwise mistreated. The final act, with its convoluted complexity and concluding scene involving explanations, revelations, and repatriation, makes the play quite different from other Shakespearean works with which Berlin audiences might have been familiar. That was exactly Berger's point: Berlin audiences needed to see an unfamiliar play by Shakespeare staged in an unfamiliar way. More to the point, the Berlin of October 1919 was a city in defeat, whose atmosphere was charged with accusation, recrimination, and conspiracy. In this unsteady climate Berger saw the underlying message of Cymbeline: reconciliation. The message of reconciliation became clear only when he removed scenic obfuscation, and his attempt at clarity was largely successful. "This is the message of the Shakespeare who has become mature and wise," said Siegfried Jacobsohn of Berger's production. "Court and state, business and the military, ambition and other passions... must be overcome, because they restrain the human spirit... It is probably no accident...that Berger has tried to preach his message only after the collapse of Europe." 6

It was, of course, no accident; nor was it accidental when, one year later, Leopold Jessner followed Berger's example in the first Shakespearean staging at the newly renamed Staatliches Schauspielhaus in Berlin. This theatre was the former Königliches Schauspielhaus, the only theatre in the city to receive a Prussian state subsidy. As Intendant of the theatre Jessner had financial freedom to mount productions more experimental in style than could other, nonsubsidized houses. The theatre's first and perhaps most daring experiment, however, was hiring Jessner in the first place. Leopold Jessner (1878-1945) had had a successful career as a director in Hamburg and Königsberg before the war, but his Jewishness and his membership in the Social Democratic Party would have made his appointment to head such a prestigious theatre during the Wilhelminian period unthinkable. After the war, those very religious and political attributes, along with his whole-hearted support of the republic, made his candidacy feasible. Jessner's approach to Shakespeare likewise exemplified the new spirit of the age. He, like Ludwig Berger, felt that Shakespeare had suffered from cultural canonization in productions of previous years.

Jessner thus conceived of a production which would address problems besetting the republic. The play he chose was Richard III, and his production 
became the most well known of the works here under discussion. Critics and theatre historians since the production's premiere in 1920 have fully documented the use of "Jessner steps" and other innovations; some have even described the production as "expressionistic." To interpret Jessner's innovations as "expressionistic," however, omits the premise upon which they were based. That premise was one that focused not upon the duke of Gloucester himself but upon Gloucester's career; the "Jessner steps" (which were actually the creation of Jessner's designer Emil Pirchan) were comprised of a large stair unit which appeared late in the play, after Gloucester's coronation. Prior to the steps' appearance, Jessner (like Berger) had reduced the stage to its Elizabethan essentials. Both Jessner and Pirchan (1884-1957) felt such reduction necessary in order to emphasize the "career" theme, since both were intent upon presenting the figure of an ambitious politician in the winter of his discontent. Such a figure was a familiar one to German audiences in 1920, and Jessner felt free to place a heavy emphasis upon thought, and to employ what some critics have called heavy-handed symbolism. Actor Fritz Kortner, as Gloucester, appeared in the first scene dressed completely in black before a black curtain; Reinhard Müthel, as Richmond, appeared at the play's conclusion dressed completely in white poised against a completely white backdrop. Richmond's followers likewise appeared in white, while Richard's cohort dressed in blood-red silks. At the moment of his death, Richard plummeted headlong down the famous steps, followed by a spotlight which bathed him in an eery, crimson glow.

Jessner justified his overt manipulation of the play by stating that to him, Shakespeare was neither a classic nor a modern playwright, "and should be regarded as a representative of this generation." 8 The director of Shakespeare's plays, furthermore, "in order to understand the artistic demands of his times, ...must not shut himself off from the world. Just the opposite: he must stand in the world and politically understand his times." Jessner politicized Richard III accordingly, a move that made sense in light of political events surrounding the production. The most important of these events were the attempt by the doctrinaire Marxist Karl Liebknecht to declare a "German Soviet Socialist Republic" (which led subsequently to Liebknecht's brutal murder at the hands of right-wing Freikorps militiamen), and the attempt by Wolfgang Kapp, an East Prussian politician, to overthrow the Weimar government. The latter attempt actually succeeded, however briefly, and placed Kapp in power for four days during March of 1920. Fritz Kortner argued that the audience for Richard III was acutely aware of these events, so it was logical to present to them a portrait of a determined careerist. ${ }^{10}$ Jessner was moreover determined to enlist Shakespeare in the defense of German republican democracy. Since he made no distinction between Shakespeare and a twentieth-century 
playwright, he drew a parallel between his production and the great productions of the fifth century B.C. in republican Athens. "The theatre," he said, "unless it is to stand aside from the political events of the period, must be political in the wider, philosophical sense, roughly in the way the theatre of the Greeks was religious in a philosophical sense."11 Jessner's parallel extended not only to the Greeks but also to the Elizabethans, since the "Jessner steps" represented a German visualization of the Wheel of Fortune, which had charted a career's ascent and had witnessed its fall.

The sudden end of an eminent Weimar political career figured heavily in Jessner's next important Shakespearean staging. The murder of Foreign Minister Walter Rathenau in June of 1922 animated the director's production of Macbeth that year, and the idea that supported the production was that of a society thrown into chaos by political assassination. Rathenau's death had sent shock waves through the Weimar Republic, and in Berlin, four months later, that shock was still palpable. As news of Rathenau's assassination had spread, thousands of Berliners walked off their jobs in protest and joined other mourners in street demonstrations. Rathenau's body lay in state for two days, as hundreds of thousands of Berliners joined processions of mourning which blocked streets and thoroughfares for hours. At the funeral, Minister of Culture Edwin Redslob ordered the orchestra to play the funeral music from Wagner's Siegfried; that Rathenau was a Jew made no difference, as Redslob noted: "He was not really a Siegfried, but all of Germany's heroes, like Rathenau and Siegfried, get stabbed in the back."12

Neither was Rathenau a Duncan; but the ignominy of "this atrocious crime," as President of the Republic Friedrich Ebert phrased it, "which has struck not only at Rathenau the man but at the whole German people," was obvious to everyone in the audience of Macbeth. The production opened November 10,1922, and Jessner with designer Pirchan fashioned a somewhat stylized setting for the play. It included tiered, architectonically manipulated spaces which specifically located Inverness, Dunsinane, and Birnam Wood. These spaces were bordered by stylized walls and towers placed at oddly pitched angles to the stage floor. Visual stylization found its most startling expression in the extreme length of the spears carried by opposing armies; this technique Jessner borrowed from the Gordon Craig production of Hamlet at the Moscow Art Theatre in 1912, although the spears were actually longer than in the Craig production. The sight of spears three times normal length, along with the stylized pitch of the walls and towers, led some critics to describe the production as "distorted." Critics used the same complaint to describe Fritz Kortner's performance in the title role. When he played Gloucester two years earlier, Kortner had used distorted, almost spasmodic movement for the role (he had, for example, galloped about the stage like a 
child with a stick-horse during the "My kingdom for a horse" scene); as Macbeth, Kortner distorted his voice. Some scenes he spoke so quietly as to be barely heard, others he shouted fortissimo. Such was the case in Act II, Scene 2 with Gerda Müller as Lady Macbeth; his hands bloody from the murder of Duncan, Kortner shouted his lines to her. She replied in a whisper; then he spoke quite rapidly, to which she responded very slowly; then he whispered; she shouted back at him.

In order to amplify the shock of assassination, Jessner paid special attention to the portrayal of minor roles. Actors playing Menteith, Caithness, Angus, and other Scottish lords, for example, stood stock still until spoken to by Kortner, whereupon they reacted suddenly and unpredictably. As in Richard III, colors also played off one another as symbols, said one critic, "of blood and death." 13 Jessner, in other words, created an analogy between Macduff's Scotland and the German Fatherland; the director translated, in this production, Macduff's lament literally to the stage: "Bleed, bleed, poor country... O nation miserable!"

Germany was indeed hemorrhaging, both politically and economically. Between the time of its inception in 1919 and the premiere of Macbeth (a period of almost three years), the republic had suffered a succession of eleven governments, and the mark had dropped 80 per cent in value against the dollar. Nor was any end in sight to the political and economic chaos by the beginning of 1923. On January 11, French and Belgian troops occupied the Ruhr industrial region in retaliation against Germany's failure to maintain reparation payments. Cut off from its main industrial base, the German economy began uncontrollably to flounder. By October of 1923 it required literally trillions of marks to buy a loaf of bread or to mail a letter. This kind of inflation visited terrible hardship on nearly everyone, and it nearly wiped out the theatre in Berlin. The educated middle class, which had comprised most of Berlin's audience, simply could no longer afford tickets to the theatre. The crisis served, however, to pump new blood into Berlin's theatrical corpus; as the more established theatres were forced to fall back onto more "reliable" interpretations of Shakespeare, numerous independent production groups came into being during 1924. These groups gave directing opportunities to many newcomers, among them Erich Engel (1891-1966). Engel had, along with Bertolt Brecht, devised a remarkable adaptation of Marlowe's Edward II at the Kammerspiele in Munich; when the theatres in Berlin began to make a comeback under the benefits of the Dawes Plan, ${ }^{14}$ Engel got the opportunity to direct his first Shakespeare play.

The play was Coriolanus. Engel's production was in some ways a reflection of Edward II, in that the hero was "distanced" from the audience's empathic response, an embryonic evidence of Brecht's Verfremdungseffekt. In 1925, 
audiences were used to pathetically histrionic treatments of Coriolanus; Engel's treatment was completely unsympathetic. It was indeed alienating, for Coriolanus was anything but a hero. "Thou hast a grim appearance," says Aufidius to Coriolanus at one point, and "grimness" characterized both Fritz Kortner's performance of the title role and the entire production. Everyone, said critic Paul Wiegler, "carried the look of hunger on their faces."15 Engel had a special purpose in mind with his "anti-heroic" staging; it was a staging with a particular significance, said Monty Jacobs in the Vossische-Zeitung, for "a shattered Germany." Here was "an aristocrat who despises the people, the people are cowards, their representatives are demagogues [and]...the mob changes its disposition hourly. ... Coriolanus is a drama of pride and the production emphasizes the political ramifications of pride: on the right there is saber-rattling at the front, on the left the homeland is stabbed in the back." Engel, he concluded, "takes the glitter off the war and presents it in field gray with an odor of decaying bodies." Here, soldiers do not seek the bubble reputation even in the cannon's mouth; they are instead "cannon fodder" sacrificed for the honor of their commanders. ${ }^{16}$

Coriolanus was thus a production about the absence of heroism in a country which had run out of heroes: on the very evening of this production's premiere, President of the Republic Friedrich Ebert died at the age of forty-four amid accusations of misconduct in office, shady financial dealings, and charges of corruption. His successor was Field Marshall Paul von Hindenburg, whose claim to heroism in World War I was dubious, and who afterwards took the distinctly unheroic step of turning the reins of power over to Adolf Hitler, an act of non-heroism which led to the republic's ultimate destruction.

By 1925, when Hindenburg assumed the presidency, the perception was already widespread that something was singularly rotten in the Weimar Republic, despite the moderation of economic decay and the measure of political stability during the first years of Hindenburg's tenure. There were moves afoot, for example, to re-establish censorship with the passage of an "anti-obscenity" statute in the Reichstag. There were also efforts in the Prussian State Legislature to oust Leopold Jessner from his post as Intendant of the Staatliches Schauspielhaus. Amidst these conspiracies Jessner decided that the time was ripe for a production of Hamlet.

This production had a novel "documentary" style; it took an unusually realistic approach perhaps in keeping with a movement which subsequently came to be known as "die neue Sachlichkeit," or "new matter-of-factness."The movement was a kind of neorealism, which was essentially a reaction to the distortions of expressionist styles and a return to "recognizable" modes. The characters and settings in this production of Hamlet, however, were so recognizable that they nearly cost Jessner his job. The production portrayed 
Claudius, for example, with a shrivelled arm reminiscent of the defunct Kaiser Wilhelm II, and Polonius with a strong resemblance to Theobald von Bethmann-Hollweg, longtime chancellor to the Kaiser. This was not "an exercise in historicism," Jessner replied to his detractors, "but an attempt to capture the metaphysical spirit of history."17 To that end the director hired Caspar Neher (1897-1962), the designer with whom Engel and Brecht had worked in Munich and who had designed Engel's production of Coriolanus. For Hamlet, Neher designed costumes to replicate military and diplomatic garb of the late Wilhelminian period, and he created a realistic set design with exterior scenes comprised of familiar-looking towers, battlements, and terraces; interior scenes included overstuffed sofas and upholstered chairs of the period. Both director and designer wanted to remind the audience that rottenness evident in the Weimar Republic had its roots in the era when the Kaiser, Bethmann-Hollweg, Hindenburg, and the like were in their prime, which implied that Hindenburg carried with him as president of the republic a certain odor of the ancien regime.

Neher located the odor specifically in his design for the play-within-the-play of Act III, Scene 2. For this scene, Neher created a theatre-within-a-theatre, an ornate little baroque playhouse on the stage of the Staatliches Schauspielhaus itself. It duplicated the intimate little theatres found in ducal residences throughout Germany, and Jessner peopled it with duplicates of what had been the power elite in Germany before the war. The natural allies of this elite, the audience was reminded, were nationalism and militarism, two forces which were gaining strength under Hindenburg's presidency. This production portrayed the nationalists and militarists as villains; the nationalists and militarists in the Prussian State Legislature responded with a parliamentary motion of censure against Jessner which recommended that the director be relieved of his duties as Intendant of the state-subsidized theatre. The censure motion failed to pass, but Jessner came increasingly under attack from the right as the decade wore on. One segment of the right was most vituperative: the National Socialists insisted that Jessner's Jewishness had "polluted" German culture, and they accused Jewish actors whom Jessner engaged of misinterpreting the great Shakespearean roles; one critic accused Kortner of playing Hamlet "like a Yeshiva student."18 Kortner doubtless failed to imbue the part with its "inborn Germanic nature."

The National Socialists in Berlin, led by Josef Goebbels, increased their attacks upon Jews in the theatre during the latter half of the decade. Kortner responded to these attacks in his performance of Shylock in The Merchant of Venice, directed by Jürgen Fehling (1885-1965), which premiered November 17, 1927. This premiere took place soon after a large Nazi party congress in Nuremberg, where the party's racial theories and a call for a general purge of 
the "German soul" received national attention. In response to the Nazis, Fehling created a production which emphasized the alienation of the Jew within a society which was divided against itself. Fehling saw Shylock as one caught in a situation where everyone, not just the Jew, was wretched, and from which there was little opportunity for escape. In the courtroom scene, for example, Fehling placed onstage a large chorus which booed and hissed in response to nearly everything Kortner said, and debated vociferously among themselves in response to Elisabeth Bergner as Portia. Monty Jacobs described the production as a depiction of three worlds locked in mortal combat: "The fantasy land of Belmont," "the cavalier world" of the ducal palace and the mercantile exchanges, and the dark world of the ghetto. "When Bassanio chose the right casket, he is wreathed in roses," wrote Jacobs, which contrasted sharply "with the thorns of Shylock's world." 19 The contrast among the various worlds of the play paralleled the contrast between Jacobs' review and the one written by Ludwig Sternaux for the right-wing Lokal-Anzeiger: "How foreign this character appears to our contemporary life," he said, denying the similarity of an increasingly strife-torn Berlin and a bigoted, intolerant Venice; he dismissed the whole idea as "barbaric" and "absurd."20

Sternaux expressed his views with unconscious irony, but his reaction, so much at variance with that of Monty Jacobs, reflected the divisions within German society, and it was that reflection which Fehling had sought to portray. The production also elicited an unexpected, ominous response which Fehling had not anticipated. The Merchant of Venice was staged at the Staatliches Schauspielhaus, and even though Jessner had not personally directed it, it had appeared under his auspices as Intendant; in 1928, when Chancellor Wilhelm Marx brought nationalists into his cabinet, right-wing, anti-Semitic forces were emboldened to dispose of Jessner once and for all. Their attempts were blunted, ironically, by claims in Jessner's defense that the director had been instrumental in raising the standards of the German theatre, and in so doing had caused the world to acknowledge Berlin's theatre life in general and the Shakespeare productions at the Staatliches Schauspielhaus in particular as among the very best anywhere. Jessner and his colleagues had "raised the cultural standards of the entire state," maintained critic Alfred Kerr. "Such standards are not to be found elsewhere in Europe or in America. Berlin: world capital."21 Most of Jessner's detractors were forced to concede that point, and to agree that the controversies surrounding the productions, especially those of the Shakespeare plays, were testimony to the high state which German theatre art had achieved.

Shakespeare had thus come full circle in the Weimar Republic. What had formerly served as a benchmark of the achievements of traditional German culture now became a bastion for the defense of innovation in German culture. 
Alfred Kerr's encouraging words emboldened Jessner to mount his final important Shakespeare staging (and the last staging to be considered here), King John. With it he gambled on a style first employed by Engel, subsequently popularized by Erwin Piscator, and ultimately defined by Brecht in his Kleines Organon für das Theater; Jessner attempted to turn King John into a Zeitstück. For this purpose he provided a narrator who announced the title and principal action of every scene, aided by charts, genealogical tables, and maps of disputed territory. Jessner's previously espoused style of using a single motive or idea to determine a production's overall style he now completely discarded. He disallowed pathos for the characters and permitted only "information" about them to reach the audience through the narrator (played by Heinrich Schnitzler, son of the Viennese playwright Arthur Schnitzler). In other words, Jessner altered the play and, in the words of critic Herbert Ihering, replaced "emotional chaos with ordered cognition."22

The style Jessner chose was as unique for King John as had been the style for Richard III nearly a decade earlier. But if Richard III lent itself to thematic, almost "expressionistic" emphasis, King John was not a play which lent itself to "epic" treatment. The play's fundamental concerns are emotional; its specific political reference is patriotism, and British patriotism at that. Jessner had hoped that scenes of violent clashes between strongly partisan armies would remind audiences of fierce street fighting taking place in Berlin between Nazi and Communist sympathizers. The actors, however, attempted to dampen emotional involvement with their roles, and the unfortunate result was "deserts of violence interspersed with oases of lyricism."23 It was also Jessner's mistake, said Alfred Kerr, to think of the play as a Zeitstück, since the one real political issue in the play (which he described as "British patriotic antagonism towards the papacy") could not be equated with anything in German politics. ${ }^{24}$

The failure of King John helped bring about the end of Jessner's tenure at the Staatliches Schauspielhaus. It was nearing its end anyway as political events, with the collapse of the American stock market, began to wreak havoc and destruction upon Weimar cultural institutions. As the ensuing economic crisis deepened, the political right went into its ascendancy, and Jessner was finally forced out in January of 1930; theatres in Berlin (and in the rest of Germany) once again resorted to "safe" interpretations of Shakespeare, and actors, directors, and designers (especially if they were Jews) began to look for ways to make a living outside Germany. Some began to leave in 1931 and 1932; when the day that Hitler assumed power in 1933 finally arrived, the trickle making an exit turned into a flood.

The flood tide swept away the greatest concentration of theatrical talent the German nation had ever nurtured. This talent included not only the skills the 
artists possessed; it also embraced a unique perception of William Shakespeare and the significance of his plays for German audiences. The innovation brought to the production of the plays and the use made of them for social and political purposes have rarely been equalled in Germany or anywhere else. The Weimar period, or "the Golden Twenties" as they are now affectionately known, was thus a Periclean Age as Alfred Kerr had maintained; it was an age in which audiences viewed Shakespeare's plays much in the way the original Elizabethan audiences had viewed them: with a sense of adventure and with a willingness to regard Shakespeare merely as a playwright and not as a member of the nation's cultural pantheon. Jessner, Fehling, Engel, Berger, and their colleagues nurtured that willingness in their audiences, just as they encouraged actors and designers to present the timeless work of Shakespeare within a framework of interpretation more accessible than at any time since the writing of the plays. In the Weimar Republic, Shakespeare (like Othello) lost his occupation; in its place he gained the active status of an artist by whom a society saw its own reflection, and whose works became indeed the abstract and brief chronicles of the time.

\section{NOTES}

1 August Koberstein, "Shakespeare in Deutschland," Deutsches Shakespeare Jahrbuch 1 (1865), 7.

2 Reinhardt's first production of $A$ Midsummer Night's Dream premiered in 1905 at the Neues Theater in Berlin; four subsequent productions of the play remained in the neo-Romantic style of the original. Reinhardt's first Shakespearean staging in the Weimar period, As You Like It, premiered February 27, 1919, at the Deutsches Theater, and it was similar in style and approach to the Midsummer Night's Dream extravaganzas; it was, according to Hugh Rorison in his notes to Erwin Piscator's The Political Theater (New York: Avon, 1978), "wholly at odds with the times, and it turned out to be the lightest, most delicate, happiest thing he had ever done." Reinhardt's other notable Shakespearean stagings in the period appeared at the Grosses Schauspielhaus; Hamlet opened there on January 17, 1920, and Julius Caesar followed on May 28, 1920. Both productions failed, due in part to acoustical problems in the Grosses Schauspielhaus and to the acknowledged unmanageability of that space's playing area.

3 Gerhart Hauptmann, “Deutschland und Shakespeare," Deutsches Shakespeare Jahrbuch 51 (1915), xii.

4 Ludwig Berger, Theatermenschen (Velber bei Hannover: Friedrich, 1962), p. 17.

5 Ludwig Berger, "Der Schauspieler," Das junge Deutschland 2 (1919), 262.

6 Siegfried Jacobsohn, rev. of Cymbeline, Theater für die Republik, ed. Günther Rühle (Frankfurt: S. Fischer, 1967), p. 166.

7 "My production style," said Jessner, "has nothing in common with that anarchy which manifests itself as the expressionist style." Theater in unserer Zeit, ed. Günther Rühle (Frankfurt: Suhrkamp, 1976), p. 58. Rühle describes Jessner's style as one characterized by "expressivity" rather than by "expressionism." 
8 Rühle, Theater in unserer Zeit, p. 69.

9 Leopold Jessner, Schriften (Berlin: Henschel, 1979), p. 56.

10 Fritz Kortner, Aller Tage Abend (Munich: Kindler, 1959), p. 352.

11 Michael Patterson, The Revolution in the German Theatre, 1900-1933 (London: Routledge and Kegan Paul, 1981), p. 114.

12 Otto Friedrich, Before the Deluge (New York: Harper and Row, 1972), p. 140.

13 Ludwig Sternaux, rev. of Macbeth, Theater für die Republik, p. 413.

14 The Dawes Plan was a reparation scheme devised by a commission headed by the American banker Charles G. Dawes (1865-1951). The commission presented a plan, subsequently adopted by the Weimar government, to stabilize the collection of the German war debt. It provided for the evacuation of the Ruhr area by French and Belgian forces and for new sources of tax income which could be applied to reparation payments. For his efforts, Dawes was awarded the Nobel Peace Prize for 1925.

15 Paul Wiegler, rev. of Coriolanus, Theater für die Republik, p. 619.

16 Monty Jacobs, rev. of Coriolanus, Theater für die Republik, p. 622-23.

17 Leopold Jessner, “Das Theater, ein Vortrag," Die Szene 17 (1928), 70.

18 Felix Hollaender, rev. of Hamlet, Theater für die Republik, p. 765.

19 Monty Jacobs, rev. of Merchant of Venice, Theater für die Republik, p. 828.

20 Ludwig Sternaux, rev. of Merchant of Venice, Theater für die Republik, p. 829.

21 . Rühle, Theater für die Republik, p. 940.

22 Herbert Ihering, rev. of King John, Von Reinhardt bis Brecht (Berlin: Aufbau, 1959), p. 65.

23 lhering, p. 66.

24 Alfred Kerr, rev. of King John, Theater für die Republik, p. 943. 